\title{
September 2005 mega-dike emplacement in the Manda-Harraro nascent oceanic rift (Afar depression)
}

\author{
Atalay Ayele, ${ }^{1,2}$ Derek Keir, ${ }^{3}$ Cynthia Ebinger, ${ }^{4}$ Tim J. Wright, ${ }^{3}$ Graham W. Stuart, ${ }^{3}$ \\ W. Roger Buck, ${ }^{5}$ Eric Jacques, ${ }^{6}$ Ghebrebrhan Ogubazghi, ${ }^{7}$ and Jamal Sholan ${ }^{8}$
}

Received 15 June 2009; revised 11 August 2009; accepted 19 August 2009; published 20 October 2009.

[1] Local and regional seismic data constrain the spacetime history of deformation and likely magma sources for the September 2005 diking episode in the Manda-Harraro rift zone of the Afar depression. The results distinguish three centers from which subhorizontal dike propagation progressed: two distinct sources around the DabbahuGab'ho Volcanic Complex (DVC) and the third at the Ado'Ale Volcanic Complex (AVC). The temporal development of seismicity shows that the majority of the dike volume is fed from beneath AVC and migrated laterally with an average rate of $15-30 \mathrm{~cm} / \mathrm{sec}$. This dike emplacement at a divergent plate boundary is unusual due to the rapid intrusion of a large volume of magma and the large amount of seismic moment release. We interpret this volcano-tectonic crisis as a complex interaction of multiple magma plumbing sources and lithosphere at a plate boundary under extension. Such repeated episodes will eventually shape the incipient oceanic rift morphology. Citation: Ayele, A., D. Keir, C. Ebinger, T. J. Wright, G. W. Stuart, W. R. Buck, E. Jacques, G. Ogubazghi, and J. Sholan (2009), September 2005 mega-dike emplacement in the MandaHarraro nascent oceanic rift (Afar depression), Geophys. Res. Lett., 36, L20306, doi:10.1029/2009GL039605.

\section{Introduction}

[2] How the architecture of spreading centers is affected by magmatic processes is one of the key questions of plate tectonics. Studies of submarine spreading centers show that the distribution of axial magma chambers (AMCs) correlates with tectonic structure [e.g., Macdonald, 1998]. For example, axial valleys are never seen where AMCs are imaged seismically under the spreading axis [e.g., Baran et al., 2005].

[3] Insight into the volcano-tectonic link depends on observing the fundamental spreading center event: dike intrusion [e.g., Delaney et al., 1998], but this is difficult in the remote and hostile environment of the deep sea. Thus, most of what we know about such events comes from the

\footnotetext{
${ }^{1}$ Institute of Geophysics Space Science and Astronomy, Addis Ababa University, Addis Ababa, Ethiopia.

${ }^{2}$ Also at School of Earth and Environment, University of Leeds, Leeds, $\mathrm{UK}$.

${ }^{3}$ School of Earth and Environment, University of Leeds, Leeds, UK.

${ }^{4}$ Department of Earth and Environmental Sciences, University of Rochester, Rochester, New York, USA.

${ }^{5}$ Lamont-Doherty Earth Observatory, Earth Institute at Columbia University, Palisades, New York, USA.

${ }^{6}$ Institut de Physique du Globe de Paris, Paris, France.

${ }^{7}$ Eritrea Institute of Technology, Asmara, Eritrea.

${ }^{8}$ National Yemen Seismological Observatory Center, Dahamar, Yemen.
}

Copyright 2009 by the American Geophysical Union. 0094-8276/09/2009GL039605 $\sim 1 \%$ of spreading centers that occur on land in Iceland and the Afar. The 1,100 years long historical record from Iceland shows that dike events occur in sequences or episodes of 10-20 events that affect individual, $<100 \mathrm{~km}$ long, segments [Saemundsson, 1979]. In northern Iceland the episodes occur every 200-300 years, last for 5-10 years and involve dikes propagating from a magma chamber close to the segment center [Einarsson and Brandsdóttir, 1980; Einarsson, 1991]. Glacial landforms complicate the interpretation of spreading center structures in Iceland, making the Afar a unique place to study spreading center processes.

[4] The largest dike opening event ever measured occurred along part of the Manda-Harraro rift segment of Afar in September 2005 and was the first such event observed using satellite geodetic methods. InSAR (Interferometric Synthetic Aperture Radar) showed that up to $8 \mathrm{~m}$ of opening occurred on a $\sim 60$-km-long, $\sim 10$-km-deep dike [Wright et al., 2006; Ayele et al., 2007], but could not determine either the location of the source for the dikefilling magma or the time history of the event. The analysis of seismic and other data discussed here allow the timing of events before and during emplacement of this mega-dike to be clarified. Our new results suggest multiple dike sources and that the majority of dike volume was laterally emplaced from a source beneath the Ado'Ale Volcanic Complex (AVC). These results raise questions regarding the central magmatic feeding system of rift segments and the length scale of dike propagation.

\section{Tectonic Setting}

[5] The Afar depression is a highly extended region of continental to oceanic transitional crust situated at the subaerial junction of the Red Sea, Gulf of Aden and Ethiopian rift systems (Figure 1). Rifting between the Arabia, Somalia, and Nubia plates during the past $\sim 30$ My produced the $\sim 300-\mathrm{km}$-wide and $\sim 600$-km-long Afar depression formed within the Palaeogene flood basalt province [e.g., Hofmann et al., 1997]. Since $3 \mathrm{Ma}$, faulting and volcanism in Afar have localized to $\sim 10$ - $\mathrm{km}$ wide and $\sim 60$ $\mathrm{km}$ long segments with aligned chains of basaltic cones and fissure-fed flows. Individual rift segments in Afar are similar in size, morphology, structure, and spacing to the second-order non-transform segments of a slow-spreading mid-ocean ridge [e.g., Tazieff et al., 1972; Hayward and Ebinger, 1996]. Despite slow spreading rates of $<1.5 \mathrm{~cm} / \mathrm{yr}$ [Vigny et al., 2006], the segments are the loci of abundant diking and volcanism. These proto-second-order segments are commonly set within relatively straight and longer (60$100 \mathrm{~km}$ ) portions of the rift (e.g., Manda-Harraro); laterally offset from each other by accommodation zones that include 


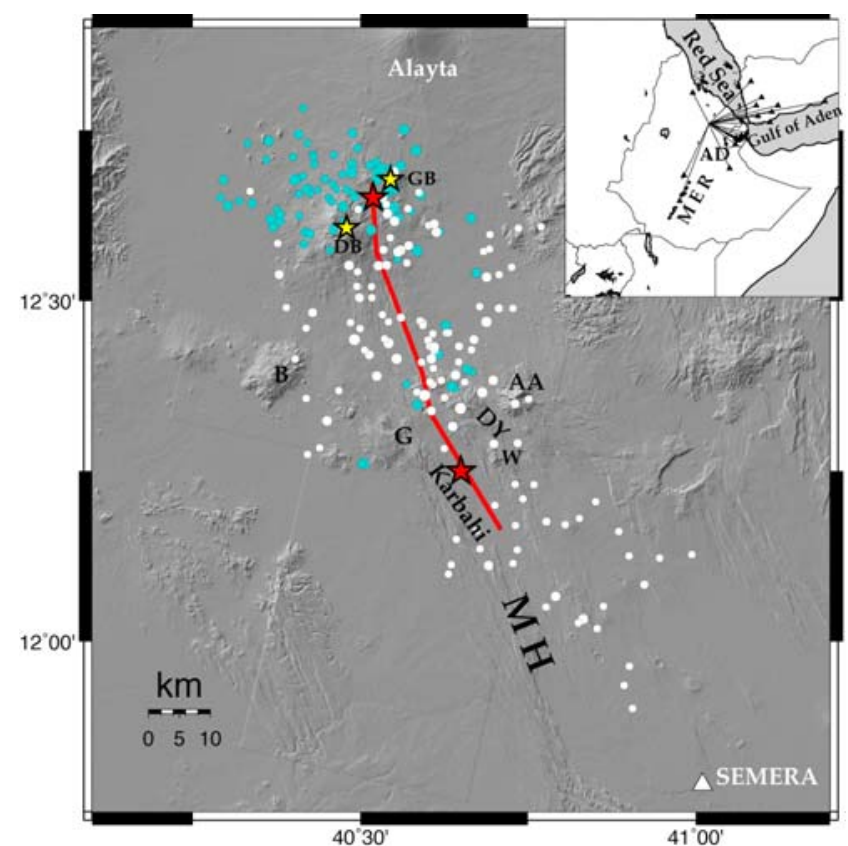

Figure 1. Earthquake distribution during the Sept. 4 to Oct. 4, 2005 episode in the Manda-Harraro rift. The red line near the rift axis shows the surface projection of the dike. Light blue circles represent earthquakes during Sept. 4-24 and white circles are epicenters during Sept. 25 to October 4. Circle size is scaled to magnitude. Yellow stars represent the Dabbahu (DB) and Gab'ho (GB) volcanoes while the red stars represent the September 26, 2005 felsic eruption at Da'Ure and the August 14, 2007 mafic eruption in the Karbahi graben south of AVC. Other acronyms are: AA (Ado Ale), DY (Diyilu), G (Gommoyta), B (Badi) W (Wa'lis) and $\mathrm{MH}$ Manda-Harraro rift zone. Top right inset shows major tectonic features in the Afro-Arabian rift system and seismic stations (triangles) distribution used in this study.

a combination of faults and aligned volcanic cones, both with highly variable strike. For example, the $\sim 120$-km-long Manda-Harraro rift includes the Dabbahu (Boina), Manda, and Harraro segments [Barberi and Varet, 1977].

[6] Manda-Harraro is a prominent segment of the Afar neooceanic ridge complex, and at its northern end sits the Dabbahu-Gab'ho Volcanic Complex (DVC) (Figure 1). Approximately $30 \mathrm{~km}$ to the south, the narrow, highly faulted and fissured rift axis is flanked on both sides by silicic volcanoes forming the AVC: to the west, Gommoyta and Badi and to the east Wol'is, Diyilu and Ado'Ale. The present study confirms that repetitive crustal deformation of the type observed at the Manda Harraro magmatic crisis in 2005 is capable of creating most of the rift architecture observed in Afar.

\section{Observations and Analysis}

[7] The spatio-temporal pattern of the 2005 diking event in the Manda-Harraro rift has been derived from all available local and regional earthquake data (Figures 1, 2, and 3), and from field observations that include eye-witness accounts from pastoralists (auxiliary material). ${ }^{1}$ Intermittent

\footnotetext{
${ }^{1}$ Auxiliary materials are available in the HTML. doi:10.1029/ 2009GL039605.
}

seismicity started beneath the DVC in April while the stronger activity commenced on September 4 with an earthquake of magnitude $4.3 \mathrm{Mw}$ at $12.54^{\circ} \mathrm{N}, 40.67^{\circ} \mathrm{E}$. On September 14, minor activity was recorded at station FURI located $\sim 450 \mathrm{~km}$ distance from the source, with a maximum magnitude of 5.0 Mw. Activity again subsided, but then restarted on September 20 and continued until October 4. This continuous two-week-long period of seismicity peaked at an intense volcano-tectonic crisis from September 24 to 26, with sporadic tremors and signals of ultra-long period ( $\sim 500$ seconds) being recorded at station FURI. On September 26, a 500-m-long, 60-m-deep, northsouth oriented vent opened at the northern end of the Manda-Harraro rift, $7 \mathrm{~km} \mathrm{NE}$ of Dabbahu volcano and close to a small volcanic cone known as Da'Ure (Figures 1, 2 , and $\mathrm{S} 1$ ).

[8] InSAR imagery indicates that Gab'ho had uplifted during the year preceding the eruption [Wright et al., 2006]. At the time of the volcano-tectonic crisis, InSAR and satellite imagery documented deformation along a $60-\mathrm{km}$ long segment of the rift from Dabbahu volcano to the south, beyond the AVC [Wright et al., 2006; Ayele et al., 2007; Grandin et al., 2009]. Intense seismicity accompanied dike intrusion along the rift zone: the epicenters of 420 earthquakes between September 4 and October 4 have been located with an absolute location algorithm, using data from the Ethiopia, Eritrea, Djibouti and Yemen national seismic networks. 210 earthquakes with magnitude $\mathrm{Mw} \geq 3.6$ are relocated using a double-difference algorithm (Figure 1 and auxiliary material). Ground-based observations attest to substantial fault growth of $2-3 \mathrm{~m}$ horizontal and $\leq 3 \mathrm{~m}$ vertical offsets [e.g., Rowland et al., 2007].

[9] The well constrained earthquake epicenters cover a $120-\mathrm{km}$-long by $25-\mathrm{km}$-wide swath, significantly longer and broader than the dike intrusion zone inferred from InSAR data [Wright et al., 2006; Grandin et al., 2009]. Homogenizing the $m_{b}$ magnitudes of the NEIC (National Earthquake Information Center) catalogue (auxiliary material), at least 25 earthquakes of magnitude $\mathrm{Mw} \geq 5.0$ are identified. The September 2005 mega-dike episode generated significant co-intrusion slip manifested by larger magnitude

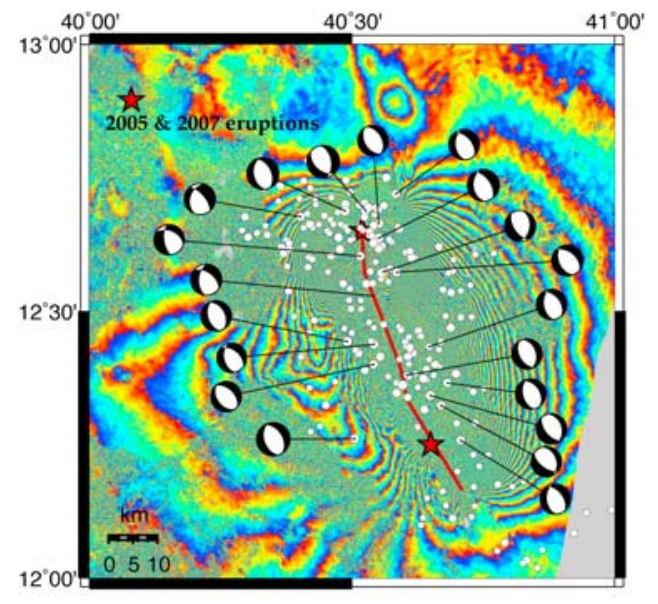

Figure 2. Seismicity (white circles) as in Figure 1 and fault plane solutions of major earthquakes displayed on the descending track 49 interferogram constructed using radar images acquired on 6 May and 28 October 2005. 


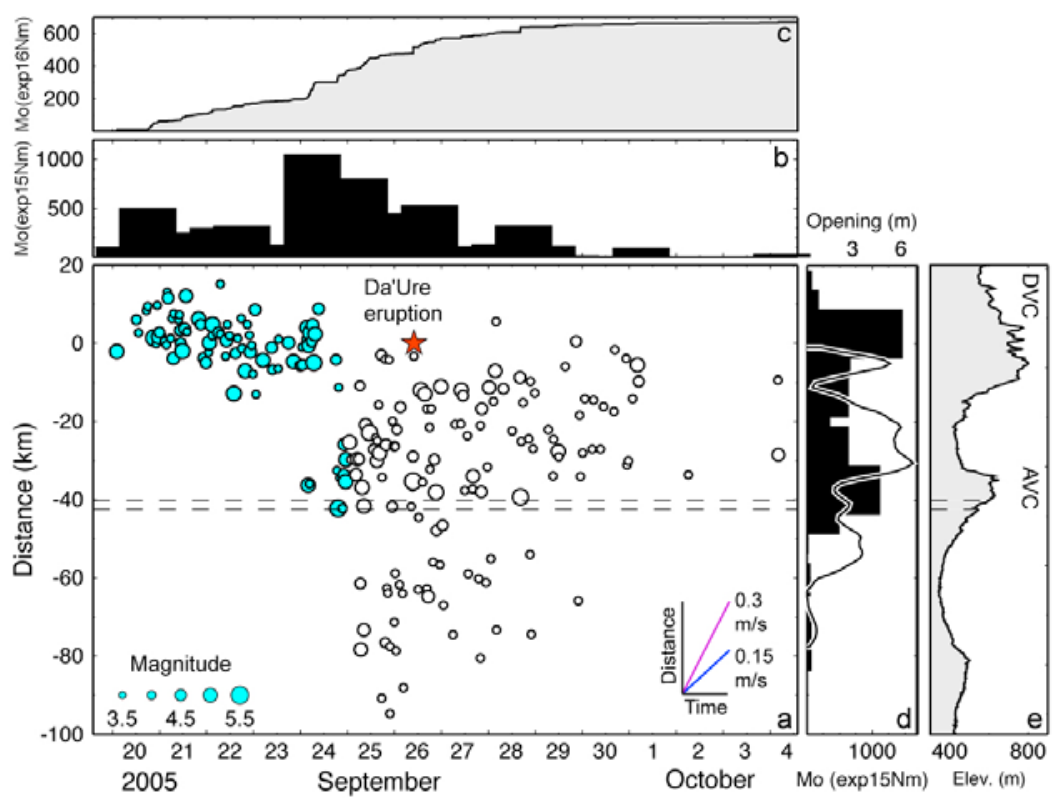

Figure 3. (a) Position of earthquakes along the Manda-Harraro rift plotted against event origin time, showing migration of seismic activity. Purple and blue lines in the bottom right corner illustrate migration velocities of $0.3 \mathrm{~m} / \mathrm{s}$ and $0.15 \mathrm{~m} / \mathrm{s}$, respectively. Earthquake position is defined by projecting epicenters onto the plane of the dike. Earthquakes are colored as in Figure 1. Two parallel dashed lines define the estimated position of the dike source beneath AVC. (b) Histogram shows seismic moment release at 12 hour intervals. (c) Cumulative seismic moment release against time. (d) Black curve shows along-dike variation in horizontal opening modeled from InSAR data [Hamling et al., 2009]. Histogram shows seismic moment release in 5-km intervals. (e) Along-rift topography. DVC is Dabbahu Volcanic Complex, and AVC is Ado'Ale Volcanic Complex. Red star shows the September 26, 2005 eruption site.

earthquakes over a period of some ten days compared to other well-recorded diking episodes documented previously [Einarsson and Brandsdóttir, 1980; Rubin and Gillard, 1998; Tolstoy et al., 2001; Ebinger et al., 2008]. Rubin and Gillard [1998] have shown that, comparing diking episodes, the accompanying number and size of earthquakes ranges widely according to the pre-existing stress state in the particular rift zone of interest. Certainly the Manda-Harraro dike intrusion followed a period of at least several decades if not centuries of quiescence. From InSAR data, the topographic trough between the DVC and the AVC showed maximum horizontal opening (Figures $3 \mathrm{~d}$ and $3 \mathrm{e}$ ) but was relatively aseismic, and implies significant strain was predominantly accommodated by magmatic accretion.

[10] The Global CMT (Centroid Moment Tensor) solutions of the twenty major earthquakes in the sequence show three strike-slip mechanisms, the rest being normal. However, there were no strike-slip offsets observed on ground breaks. Close examination of the regional seismograms reveals overlapping waveforms that produce a complex $\mathrm{P}$ wave group and resulted in anomalous strike-slip Global CMT solutions. P-wave first motion readings and moment tensor inversion have been employed to verify the strikeslip fault plane solutions, which were found here to be normal (Figures 2 and S2).

\section{Time Sequence and Rate of Dike Intrusion}

[11] The position of epicentres projected onto an alongaxis profile and plotted against event origin time is displayed in Figure 3a. The DVC remained seismically active during 20-23 September and then became quieter at about 09h17 GMT on September 24. After a 9-hour hiatus, activity resumed, but jumped $30 \mathrm{~km}$ south to the AVC where it was initiated by an earthquake of magnitude $\mathrm{Mw}$ 4.2 (Figures 1 and 3a). A further hour later, an earthquake of magnitude Mw 5.4 at some $9 \mathrm{~km}$ depth beneath the western flank of the Gommoyta volcanic dome signalled the onset of bidirectional migration of seismicity. While southward migration of earthquakes is less well constrained owing to fewer earthquakes, a clear and intense northward migration along the rift segment from AVC proceeded at an average rate of $15-30 \mathrm{~cm} / \mathrm{s}$ (Figure $3 \mathrm{a}$ ). This is slow compared with a $50-200 \mathrm{~cm} / \mathrm{s}$ migration rate at Krafla [e.g., Brandsdóttir and Einarsson, 1979], and with that of smaller dikes in the post-2005 eruption period at Manda-Harraro [e.g., Keir et al., 2009] but faster than the $\sim 0.22 \mathrm{~cm} / \mathrm{s}$ rate for the ultraslow spreading Gakkel ridge [Tolstoy et al., 2001].

\section{Discussion and Conclusions}

[12] At least three distinct magma feeders are recognized from the September 2005 rifting episode in the Manda Harraro rift zone (Figure 3a). Activity started beneath and around both Gab'ho and Dabbahu volcanoes at the northern end of the rift on September 20, where it persisted for four and a half days before jumping $30 \mathrm{~km}$ south to the AVC where the major diking then commenced. The diking events are revealed in spatially and temporally distinct earthquake swarms.

[13] The southward jump in seismicity to the AVC zone on September 24 suggests that the earlier activity destabilized an unconnected crustal magma reservoir beneath the central rift sector that was at or near critical stress state 


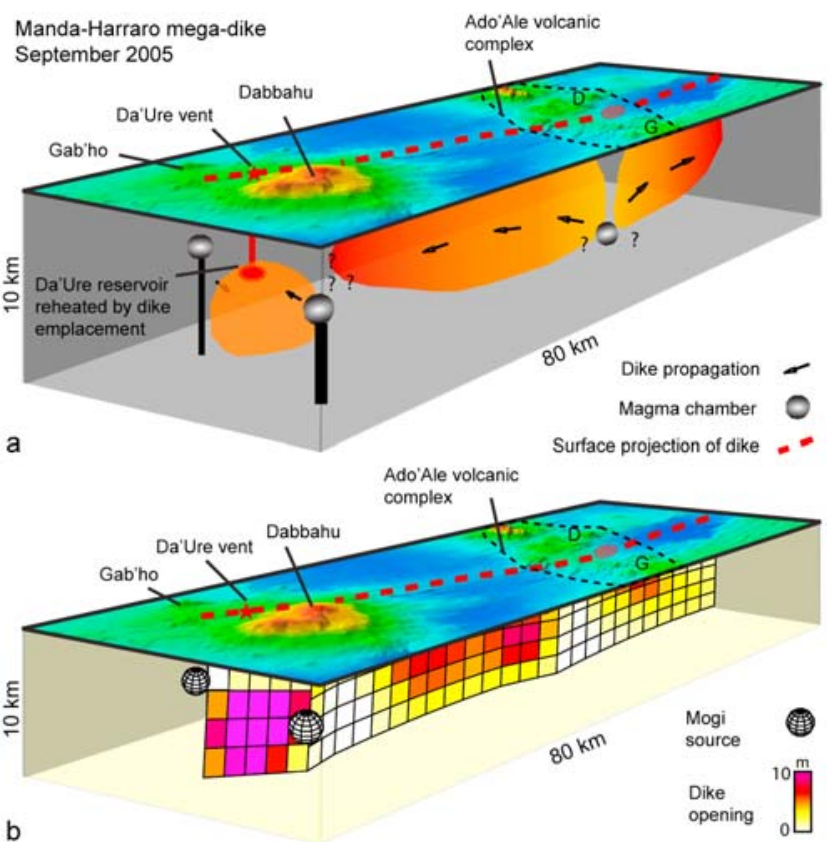

Figure 4. (a) Cartoon interpretation of the volcanic system activated in the Manda-Harraro rift during the September 2005 episode. Gray shaded ellipses show magma chambers that feed dikes, which are shaded orange. Deflating magma chambers at $\sim 3-5-\mathrm{km}$-depth beneath Dabbahu and Gab'ho are constrained by subsidence of these volcanoes observed using InSAR. The magma chamber beneath the AVC is inferred from seismicity data. However, the lack of AVC subsidence suggests the magma source is relatively deep, here positioned at $\sim 10-\mathrm{km}$-depth. The red ellipse shows the source of the felsic lavas erupted from Da'Ure vent on September 26. Question marks displayed near Dabbahu volcano demonstrate our uncertainty in the relationship between dikes sourced from DVC and those sourced from the AVC. (b) Distribution of horizontal opening on the September 2005 dike, and deflating mogi sources, modeled using InSAR data [Wright et al., 2006].

(Figures 3 and 4). Coulomb stress changes resulting from the DVC deformation are likely to have triggered intrusive activity into the central rift. The Da'Ure vent eruption on September 26, occurring 2.5 days after the DVC seismicity had quietened, coincided with the arrival of the mega-dike propagating northward from the AVC. Sanidine feldspar lathes in pumice erupted from Da'Ure show resorption, indicating that their growth was interrupted by heating prior to eruption, consistent with a basaltic dike intrusion model. The northward diking from the AVC along the MandaHarraro rift zone proposed here counters the hypothesis of a southward propagation from the DVC [Wright et al., 2006; Ayele et al., 2007] based on Mogi models of deflation patterns seen in InSAR. The existence of a volumetrically large magma source beneath the central rift segment can also explain the volume deficit of magma sourced from the DVC [Wright et al., 2006; Ayele et al., 2007]. The absence of distinct subsidence at AVC suggest that the magma source is significantly deeper than that at DVC.

[14] Within the constraints of accuracy of epicentral location applicable to this study $( \pm 5 \mathrm{~km})$, the eastern flank of the AVC was seismically more active than its western counterpart during the magmato-tectonic crisis. The implication follows of an asymmetric magmatic accretion at the rift axis, by analogy to slow-spreading ridges [e.g., Escartin et al., 1999], and is supported by the field and InSAR data [Wright et al., 2006; Rowland et al., 2007]. The longitudinal extent of earthquake distribution along the Manda-Harraro rift zone is about twice the length of the dike inferred from InSAR. Seismicity occurs up to $40-\mathrm{km}$ south of the southernmost extent of the dike and was most likely triggered by Coulomb stress changes induced by dike injection [e.g., Ayele et al., 2007]. Following the September 2005 major diking episode, the $60-\mathrm{km}$-long rift zone remained seismically active, focussed on the south flank of Dabbahu volcano and the Da'Ure vent site [Ebinger et al., 2008].

[15] In summary, the recent Manda-Harraro diking episode marks the ongoing development of an incipient oceanic rift in the Afar. This rare, large-volume dike intrusion fundamentally alters our perception of rates and scales of rift zone deformation and raises new questions regarding the storage and movement of magma in continental rift zones. The evidence for a magma source beneath the center of the rift segment during the first and subsequent dike intrusion events indicates that the intrusion of large dikes creates and maintains the rift architecture with modification from shallow fractionated magma reservoirs. The singular importance of this activity in a subaerial environment is inviting intensive international monitoring through a spectrum of geodetic, geophysical and geological techniques.

[16] Acknowledgments. We are grateful to Paul Mohr, Laike Asfaw and two anonymous referees for useful comments. A.A.'s visit to the University of Leeds is sponsored by the NERC Afar Rift Consortium (http://see.leeds.ac.uk, NE/E007414/1). D.K. is supported by NERC fellowship NE/E013945/1, CJE and WRB are supported by grants EAR0635789 and 0635898 and T.J.W. is supported by a Royal Society fellowship.

\section{References}

Ayele, A., E. Jacques, M. Kassim, T. Kidane, A. Omar, S. Tait, A. Nercessian, J.-B. Chabalier, and G. King (2007), The volcano-seismic crisis in Afar, Ethiopia, starting September 2005, Earth Planet. Sci. Lett., 255, 177-187, doi:10.1016/j.eps1.2006.12.014.

Baran, J. M., J. R. Cochran, S. M. Carbotte, and M. R. Nedimović (2005), Variations in upper crustal structure due to variable mantle temperature along the Southeast Indian Ridge, Geochem. Geophys. Geosyst., 6, Q11002, doi:10.1029/2005GC000943.

Barberi, F., and J. Varet (1977), Volcanism of Afar: Small-scale plate tectonic implications, Geol. Soc. Am. Bull., 88, 1251-1266, doi:10.1130/ 0016-7606(1977)88<1251:VOASPT $>2.0 . C O ; 2$.

Brandsdóttir, B., and P. Einarsson (1979), Seismic activity associated with the September 1977 deflation of Krafla volcano in north-eastern Iceland, J. Volcanol. Geotherm. Res., 6, 197-212, doi:10.1016/03770273(79)90001-5.

Delaney, J. R., D. S. Kelley, M. D. Lilley, D. A. Butterfield, J. A. Baross, W. S. D. Wilcock, R. W. Embley, and M. Summit (1998), The quantum event of oceanic crustal accretion: Impacts of diking at mid-ocean ridges, Science, 281, 222-230, doi:10.1126/science.281.5374.222.

Ebinger, C. J., D. Keir, A. Ayele, E. Calais, T. J. Wright, M. Belachew, J. O. S. Hammond, M. E. Campbell, and W. R. Buck (2008), Capturing magma intrusion and faulting process during continental rupture: Seismicity of the Dabbahu (Afar) rift, Geophys. J. Int., 174, 1138-1152, doi:10.1111/j.1365-246X.2008.03877.x.

Einarsson, P. (1991), The Krafla rifting episode 1975-1989, in Náttúra M'yvatns, edited by A. Gardarsson and À. Einarsson, pp. 97-139, Icelandic Nat. Sci. Soc., Reykjavik.

Einarsson, P., and B. Brandsdóttir (1980), Seismological evidence for lateral magma intrusion during the July 1978 deflation of the Krafla volcano in NE Iceland, J. Geophys., 47, 160-165.

Escartin, J., P. A. Cowie, R. C. Searle, S. Allerton, N. C. Mitchell, C. J. MacLeod, and A. P. Slootweg (1999), Quantifying tectonic strain and 
magmatic accretion at a slow spreading ridge segment, Mid-Atlantic Ridge, $29^{\circ}$ N, J. Geophys. Res., 104, 10,421-10,437, doi:10.1029/ 1998JB900097.

Grandin, R., et al. (2009), September 2005 Manda Hararo-Dabbahu rifting event, Afar (Ethiopia): Constraints provided by geodetic data, J. Geophys. Res., 114, B08404, doi:10.1029/2008JB005843.

Hamling, I., et al. (2009), Geodetic observations of the ongoing Dabbahu rifting episode: new dike intrusions in 2006 and 2007, Geophys. J. Int. 178, 989-1003, doi:10.1111/j.1365-246X.2009.04163.x.

Hayward, N. J., and C. J. Ebinger (1996), Variations in the along-axis segmentation of the Afar rift system, Tectonics, 15, 244-257, doi:10.1029/95TC02292.

Hofmann, C., V. Courtillot, G. Féraud, P. Rochette, G. Yirgu, E. Ketefo, and R. Pik (1997), Timing of the Ethiopian flood basalt event and implications for plume birth and global change, Nature, 389, 838-841, doi:10.1038/39853.

Keir, D., et al. (2009), Evidence for focused magmatic accretion at segment centres from lateral dike injections captured beneath the Red Sea rift in Afar, Geology, 37(1), 59-62, doi:10.1130/G25147A.1.

Macdonald, K. C. (1998), Linkages between faulting, volcanism, hydrothermal activity and segmentation on fast spreading centers, in Faulting and Magmatism at Mid-Ocean Ridges, Geophys. Monogr. Ser., vol. 106, edited by W. R. Buck et al., pp. 27-58, AGU, Washington, D. C.

Rowland, J. V., E. Baker, C. J. Ebinger, D. Keir, T. Kidane, J. Biggs, N. Hayward, and T. J. Wright (2007), Fault growth at a nascent slow spreading ridge: 2005 Dabbahu rifting episode, Afar, Geophys. J. Int., 171, 1226-1246, doi:10.1111/j.1365-246X.2007.03584.x.

Rubin, A. M., and D. Gillard (1998), Dike-induced earthquakes: Theoretical considerations, J. Geophys. Res., 103, 10,017-10,030, doi:10.1029/ 97JB03514.

Saemundsson, K. (1979), Fissure swarms and central volcanoes of the neovolcanic zones of Iceland, Geol. J., 19, 415-432.
Tazieff, H., J. Varet, F. Barberi, and G. Giglia (1972), Tectonic significance of the Afar (or Danakil), Depression, 235, 144-147.

Tolstoy, M., D. R. Bohnenstiehl, and M. H. Edwards (2001), Seismic character of volcanic activity at the ultraslow-spreading Gakkel Ridge, Geology, 29(12), 1139-1142, doi:10.1130/0091-7613(2001)029<1139: SCOVAA $>2.0 . \mathrm{CO} ; 2$.

Vigny, C., P. Huchon, J.-C. Ruegg, K. Khanbari, and L. M. Asfaw (2006), Confirmation of Arabia plate slow motion by new GPS data in Yemen, J. Geophys. Res., 111, B02402, doi:10.1029/2004JB003229.

Wright, T. J., C. Ebinger, J. Biggs, A. Ayele, G. Yirgu, D. Keir, and A. Stork (2006), Magma maintained rift segmentation at continental rupture in the 2005 Afar dyking episode, Nature, 442, 291-294, doi: $10.1038 /$ nature 04978 .

A. Ayele, Institute of Geophysics Space Science and Astronomy, Addis Ababa University, King George VI Street, Addis Ababa 1176, Ethiopia. (atalay@geobs.aau.edu.et)

W. R. Buck, Lamont-Doherty Earth Observatory, Earth Institute at Columbia University, Palisades, NY 10964, USA.

C. Ebinger, Department of Earth and Environmental Sciences, University of Rochester, Rochester, NY 14627, USA.

E. Jacques, Institut de Physique du Globe de Paris, F-75005 Paris, France.

D. Keir, G. W. Stuart, and T. J. Wright, School of Earth and Environment, University of Leeds, Leeds LS2 9JT, UK.

G. Ogubazghi, Eritrea Institute of Technology, P.O. Box 5604, Asmara, Eritrea.

J. Sholan, National Yemen Seismological Observatory Center, P.O. Box 87175, Dahamar, Yemen. 